\title{
Physico-chemical Characteristics of Ground Water Samples Collected from Chitrakoot Region, Satna District
}

\author{
Arvind Prasad Dwivedi
}

\author{
Lecturer, Department of chemistry, Govt. Sanjay Gandhi Smrati, auto. P.G. College, Sidhi (M.P.)
}

\begin{abstract}
The present study was investigated varicose physic-chemical parameters like Temperature, $P H, D O$, COD, TDS, TSS, Alkalinity, Total Hardness, Nitrate, Chloride and Sulphate etc. Eleven ground water samples were collected form Chitrakoot region of Satna District. Geographical information of Chitrakoot district Satna

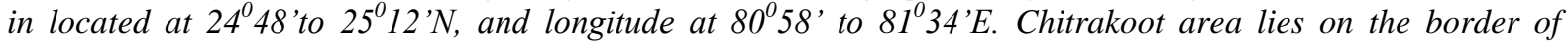
Madhya Pradesh area have great historical mythological and religious significance. The experimental values were compared with standard values recommended by world health organization (WHO). After analysis of physico-chemical Parameters of Ground Water samples from different location of Chitrakoot region, it has been observed that some parameters are within the permissible limit while few were very higher than their maximum permissible limit.
\end{abstract}

Keywords: Physico-Chemical Parameters, Ground Water, Chitrakoot Region, Satna District.

\section{INTRODUCTION}

The quality of ground water is highly related with local environmental and geological conditions. Today human activities are constantly adding industrial, domestic and agricultural waste to ground water reservoirs at an alarming rate. Ground water contamination is generally in irreversible i.e. Once it is contaminated it is difficult to degrades water quality producing an objectionable taste and excessive hardness. It is always better to protect ground water first rather than recycling on technology to clean up water from contaminated source. Polluted ground water is the major cause for the spread of epidemics and chronic diseases of man. It causes typhoid, jaundice, dysentery, diarrheic, tuberculosis and hepatitis. In India almost $80 \%$ of the rural population depends on untreated ground water for potable water supplies. As a result, farmers in the adjoining areas find the ground water unsuitable for irrigation. Drinking water wells may also get affected. Environmental problems related to industrial effluent disposal on land have been reported from various parts of the country. Disposal on creates local/regional environmental problems. Watershed management for any city requires the estimation of both point and non-point sources of water pollution. An effective land-use planning plays a crucial role in efficient management of water resources of any area ${ }^{1}$.

Geographical information of chitrakoot district Satna in located at $24^{\circ} 48^{\prime}$ to $25^{\circ} 12^{\prime} \mathrm{N}$, and longitude at $80^{\circ} 58^{\prime}$ to $81^{\circ} 34^{\prime} \mathrm{E}$ distance covered by district from east to west is $62 \mathrm{~km}$ and north to south is $57.5 \mathrm{~km}$ district is bounded in the north by kaushambi in the south by Satna (M.P.) in the east of Allahabad in the west by Banda, Distance between Satna and chitrakoot is $77 \mathrm{~km}$. The Chitrakoot area lies on the border of Madhya Pradesh area has great historical mythological and religious significance. It is believed to have sheltered lord ram for a long period during his exile. Hence river mandakini is piously called "Ganga ji" and is work shipped every day. River is believed to wash away all sins being obsessed by such faith people bathe in this river especially on some auspicious. ${ }^{2}$

The present study was investigated varicose physic-chemical parameters like Temperature, $\mathrm{PH}, \mathrm{DO}$, COD, TDS, TSS, Alkalinity, Total Hardness, Nitrate, Chloride and Sulphate etc. The ground water samples were collected different sampling stations are as Sati-anusuiya, rjola, Arogyadham, Jankikund, Pramodvan, Bus -stand, Ramghat, parikrama, Akshayvat, Peelikothi.

\section{Material AND MethodS}

Eleven ground water samples were collected form Chitrakoot region of Satna District. Sampling was done in accordance with Grab sampling method in polyethylene bottles of one liter capacity to avoided leaching of methods and interaction with the surface wall of the containers bottles were first 
cleaned with detergent and then socked in 1:1 $\mathrm{HNO}_{3}$ for 24 hours. Finally the bottles were cleaned and rinsed with distill water. During sampling bottles were two to three times with the sample to be examined before filling with it. Samples were collected by immersing the rinsed bottles in ground water $^{3-4}$.All the samples were labeled, showing the source date and time of collection. The samples were refrigerated at $4^{0} \mathrm{C}$ in the laboratory ${ }^{3-5-6}$ and analyzed for various water quality parameters as per standard procedures (AWWA, 1999) ${ }^{7}$. The experimental values were compared with standard values recommended by world health organization (WHO) and Indian standards for drinking purposes. All the sampling stations are presented in table-1

For the purpose of representative of groundwater quality in the study area following locations is

Presented the in table

Table1. List of sampling stations in Chitrakoot region

\begin{tabular}{|l|c|c|c|}
\hline S.N. & Code & Name of Sampling station & Description of Sampling Locations \\
\hline 1 & G1 & Sati Anusuiya & In front of Satianusuiya Temple, Chitrakoot \\
\hline 2 & G2 & Rajola & Govt. High School Rajola ,Chitrakoot \\
\hline 3 & G3 & M.G.C.G.V.V. & Inside the M.G.C.G.V.V. ,Chitrakoot \\
\hline 4 & G4 & Aroghadham & Infront of DRI Hospital, Chitrakoot \\
\hline 5 & G5 & Jankikund & Inside the Jankikund Hospital, Chitrakoot \\
\hline 6 & G6 & Pramodvan & Near the Court, Chitrakoot \\
\hline 7 & G7 & Bus-Stand & Chitrakoot Bus Stand Satna, Chitrakoot \\
\hline 8 & G8 & Ramghat & Near the Purani Lanka, Chitrakoot \\
\hline 9 & G9 & Kamtanath & Pratham Mukharbindu, Chitrakoot \\
\hline 10 & G10 & Akshayvat & Near the Gayatri Mandir, Chitrakoot \\
\hline 11 & G11 & Peeli-kothi & Kamtan Tola, Chitrakoot \\
\hline
\end{tabular}

\section{RESULT AND DISCUSSION}

In the present study we are analyzed some physicochemical characteristics of ground water sample in Chitrakoot region, all the values where, shown in table- 2 and graphical representation of all the parameters are presented in Fig - 1 to 11.

\subsection{Physico-Chemical Characteristics of Ground Water Samples Collected from Chitrakoot Region}

Temperature of ground water samples ranged from $24.5^{\circ} \mathrm{C}$ to $30^{\circ} \mathrm{C}$ as show in table 2 . Minimum temperature was record $24.5^{\circ} \mathrm{C}$ at Satianusuiya. Maximum temperature was record $30^{\circ} \mathrm{C}$ at Bus-stand. Pushpam etal, $2014^{8}$ studied assessment of water quality of mathusooth anapercemal swamy temple pond in Parakkai, kanya kumari and temperature was recorded varied from $28.53^{\circ} \mathrm{C}$ to $28.95^{\circ} \mathrm{C}$. The value of $\mathrm{pH}$ was found between 8.4-8.65. Minimum value of $\mathrm{pH}$ was observed 8.4 at Ramghat while maximum 8.65 at Arogyadham. Shrivastava etal, $2014^{9}$ studied ground water quality assessment of Birsinghpur Area, Satna District, Madhya Pradesh and PH Concentration was found ranged from 6.8 to 7.8. Dissolved oxygen (DO) was ranged from 5.69 to $7.80 \mathrm{mg} / \mathrm{l}$. Minimum value of DO was found $5.69-\mathrm{mg} / \mathrm{l}$ at Ramghat and maximum value $7.80 \mathrm{mg} / \mathrm{l}$ at Pramodvan. Das etal, $2013^{10}$ studied physicoChemical characteristics of selected ground water samples of Ballarpur city of Chandrapur District, Maharashtra, India and observed the Dissolve oxygen values were found ranged from 6.4 to $9.3 \mathrm{mg} / \mathrm{l}$. Chemical oxygen demand (COD) was found ranged from 12.0 to $33.3 \mathrm{mg} / \mathrm{l}$. Minimum value of COD was found $12.0 \mathrm{mg} / \mathrm{l}$ at Pramodvan while maximum value was found $33.3 \mathrm{mg} / \mathrm{l}$ at Ramghat. All the COD values of all the sampling locations are higher than the permissible limit prescribed by WHO. Chaurasia etal, $2013^{11}$ carried out Pollution sources and water quality of River Mandakini at Chitrakoot, Analyzed the Chemical oxygen Demand in mandakini River Chitrakoot found COD ranged between $12-140 \mathrm{mg} / \mathrm{l}$.

Total dissolved solid (TDS) ranged from540 to $800 \mathrm{mg} / \mathrm{l}$ and total suspended solid was found in the range of 110 to $190 \mathrm{mg} / \mathrm{l}$ as show in table -1. Minimum value of TDS 540mg/l was observed at M.G.C.G. while maximum value of TDS was found $800 \mathrm{mg} / \mathrm{l}$ at Ramghat. Minimum value of TSS 110 $\mathrm{mg} / \mathrm{l}$ was observed at Satianusuiya while maximum value of TSS was found $190 \mathrm{mg} / \mathrm{l}$ at Satianusuiya. TDS and TSS were found all the sampling stations with in limit of WHO. Mohanty etal, $2013^{12}$ Studied assessment of ground water quality due to coal mining at tilapia-I coal mine, Sumbalpur, odisha and TDS values was reported varied from 183 to $251 \mathrm{mg} / \mathrm{l}$. Alkalinity was found in the range 
of 36.8 to $200 \mathrm{mg} / \mathrm{l}$. Minimum value of Alkalinity $160 \mathrm{mg} / \mathrm{l}$ was observed at Satianusuiya while maximum value of Alkalinity $200 \mathrm{mg} / \mathrm{l}$ at Ramghat, the Alkalinity value of All the location are within the range of permissible limits set by WHO. Nitrate in ground water samples were recorded in the range of 0.68 to $20.5 \mathrm{mg} / \mathrm{l}$. Values of nitrate all the sampling locations are below the permissible limits set by WHO as $45 \mathrm{mg} / \mathrm{l}$. Suman etal, $2014{ }^{13}$ studied water quality management of water resources of Bhopal city: Challenges and Scope observed the nitrate ion ranged from $0.68 \mathrm{mg} / \mathrm{l}$ to $1.36 \mathrm{mg} / \mathrm{l}$. Chloride was recorded in the range of 19 to $39 \mathrm{mg} / \mathrm{l}$, All the Chloride Value were recorded below the recommended level set by WHO as $250 \mathrm{mg} / \mathrm{l}$. Total Hardness values were recorded in the ground water samples ranging from of $694-1688 \mathrm{mg} / \mathrm{l}$. Minimum value was found of $694 \mathrm{mg} / \mathrm{l}$ at Satianusuiya while maximum value $1688 \mathrm{mg} / \mathrm{l}$ was found at Kamtan. Total hardness values of all the sampling locations were observed higher than the permissible limits prescribed by WHO. Sunita etal, $2005^{14}$ studied hydrogeo-chemistry of ground water, gooty Area, Anantapur District, Andhrapradesh and total hardness values were found ranged between 360 to $4040 \mathrm{mg} / \mathrm{l}$.The value of sulphate was recorded in the range of 211to $360 \mathrm{mg} / \mathrm{l}$. Minimum value of sulphate was found $211.0 \mathrm{mg} / \mathrm{l} \mathrm{at} \mathrm{Peeli-}$ Kothi while maximum value was recorded $360 \mathrm{mg} / \mathrm{l}$ at Bus Stand. Tripathi etal, $2014^{15}$ studied assessment of ground water quality in Umaria District, Vindhya Pradesh India, reported the sulphate content ranged between 5.0 to $398 \mathrm{mg} / \mathrm{l}$.

Table2. Physico-chemical characteristics of ground water samples collected from Chitrakoot region

\begin{tabular}{|l|l|l|l|l|l|l|l|l|l|l|l|l|}
\hline S.N. & Parameters & G1 & G2 & G3 & G4 & G5 & G6 & G7 & G8 & Gy9 & G10 & G11 \\
\hline 1 & Temp. & 24.5 & 28.7 & 27.9 & 25 & 29.5 & 26.5 & 30 & 26.9 & 29.3 & 28.5 & 27.7 \\
\hline 2 & pH & 8.19 & 8.40 & 8.40 & 8.65 & 8.42 & 8.15 & 8.15 & 8.4 & 8.54 & 8.18 & 8.10 \\
\hline 3 & DO & 7.47 & 6.82 & 7.15 & 7.15 & 6.50 & 7.80 & 7.31 & 5.69 & 6.82 & 6.50 & 5.36 \\
\hline 4 & COD & 22.6 & 32 & 16 & 26.6 & 26 & 12 & 29.6 & 33.3 & 20 & 13.3 & 13.3 \\
\hline 5 & TDS & 562 & 583 & 540 & 623 & 670 & 720 & 750 & 800 & 740 & 710 & 705 \\
\hline 6 & TSS & 110 & 117 & 130 & 147 & 135 & 170 & 177 & 190 & 180 & 150 & 165 \\
\hline 7 & Alkalinity & 36.8 & 44.67 & 56.73 & 87.22 & 95.1 & 100 & 105 & 200 & 162 & 186 & 177 \\
\hline 8 & Nitrate & 0.68 & 20.5 & 5.52 & 20.0 & 14.9 & 3.47 & 4.01 & 18.8 & 0.68 & 6.04 & 321 \\
\hline 9 & Chloride & 22 & 19 & 24 & 33 & 39 & 35 & 36 & 38 & 32 & 30 & 27 \\
\hline 10 & Sulphate & 310 & 250 & 340 & 300 & 296 & 349 & 360 & 348 & 310 & 279 & 211 \\
\hline 11 & Hardness & 694 & 700 & 940 & 886 & 870 & 1300 & 800 & 1422 & 1688 & 1544 & 1200 \\
\hline
\end{tabular}

Table3. Water Quality Parameters and Drinking Water Standards

\begin{tabular}{|c|c|c|c|c|c|}
\hline S.N. & Parameter & \multicolumn{2}{|c|}{ WHO(1993) mg/L } & \multicolumn{2}{c|}{ BIS(1991) mg/L } \\
\hline & & Max. desirable & Max. permissible & Max .desirable & Max .permissible \\
\hline 1. & Temp. & - & - & - & - \\
\hline 2. & pH & 7.0 & 8.5 & 6.5 & - \\
\hline 3. & DO & 4 & 6 & 2.0 & - \\
\hline 4. & BOD & $6-0$ & - & - & - \\
\hline 5. & COD & 10 & - & 500 & 1000 \\
\hline 6. & TDS & 500 & 1500 & - & - \\
\hline 7. & TSS & 100 & - & 200 & - \\
\hline 8. & Alkalinity & 200 & 600 & 10 & 1000 \\
\hline 9. & Nitrate & 100 & 45 & 250 & 400 \\
\hline 10. & Chloride & 200 & 600 & 150 & - \\
\hline 11. & Sulphate & 200 & 400 & 300 & \\
\hline 12. & Hardness & 300 & 600 & & \\
\hline
\end{tabular}

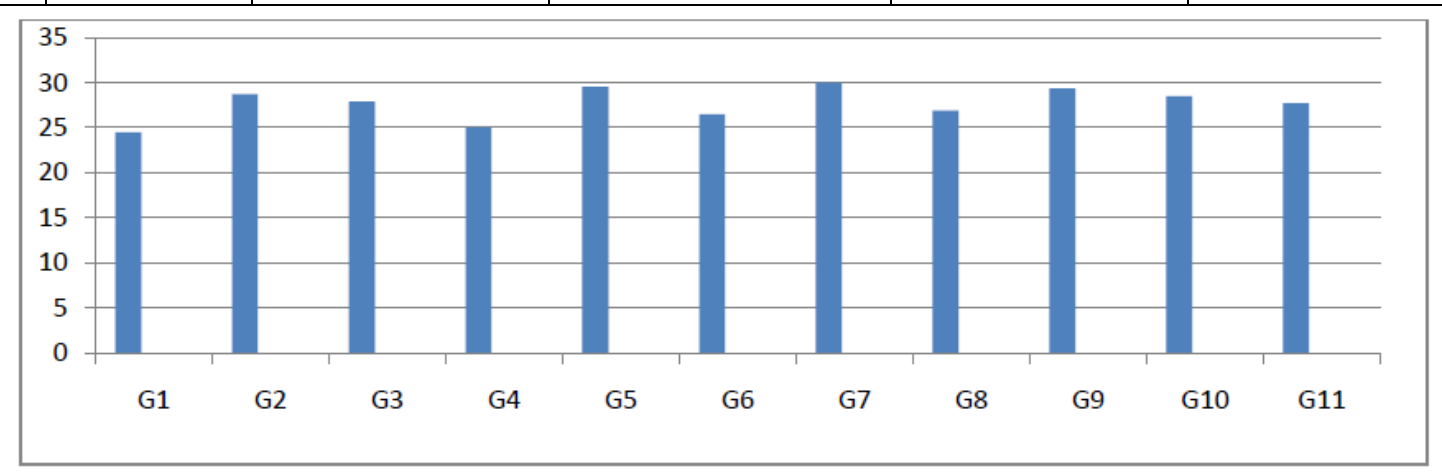

Fig1. Graphical representation of Temperature 


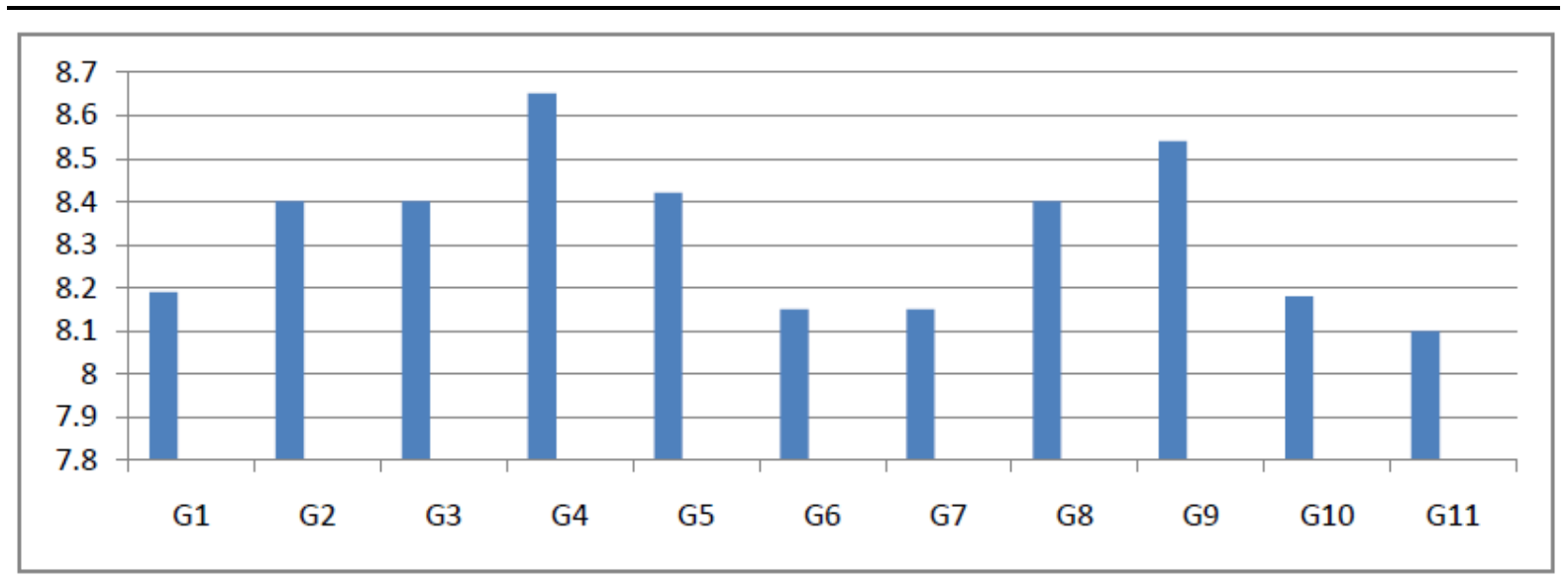

Fig2. Graphical representation of $p H$

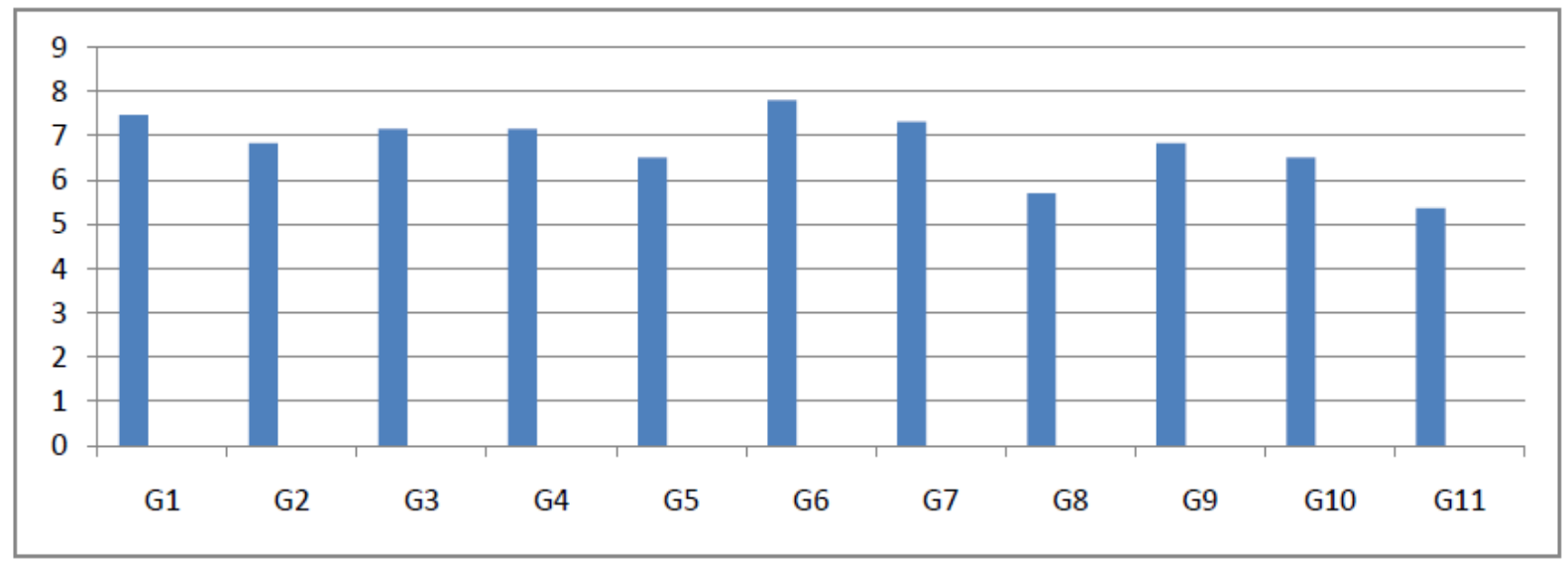

Fig3. Graphical representation of DO

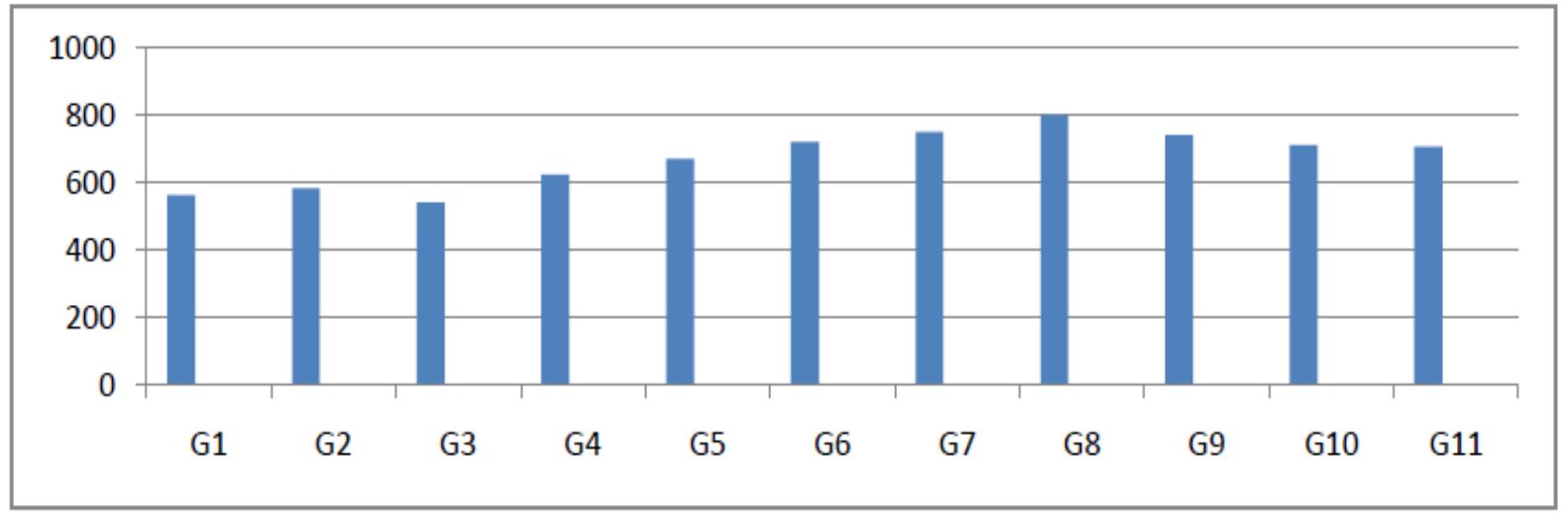

Fig4. Graphical representation of COD

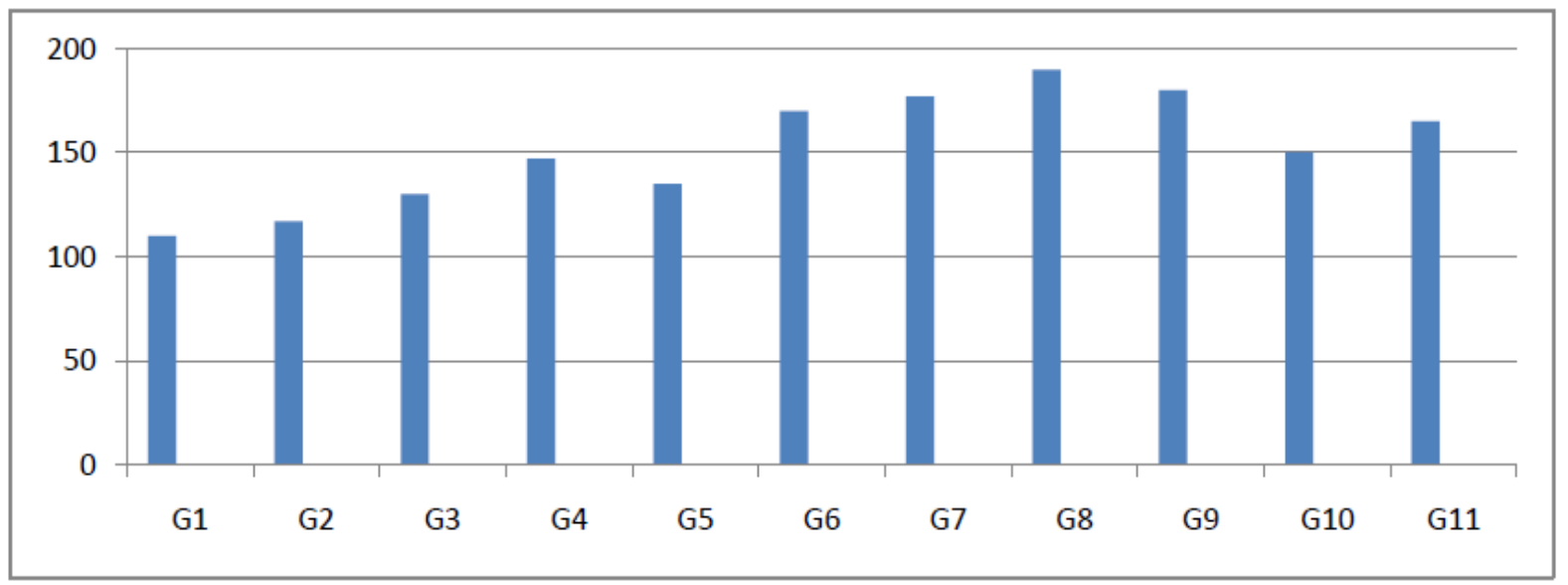

Fig5. Graphical representation of TDS 
Physico-chemical Characteristics of Ground Water Samples Collected from Chitrakoot Region, Satna District

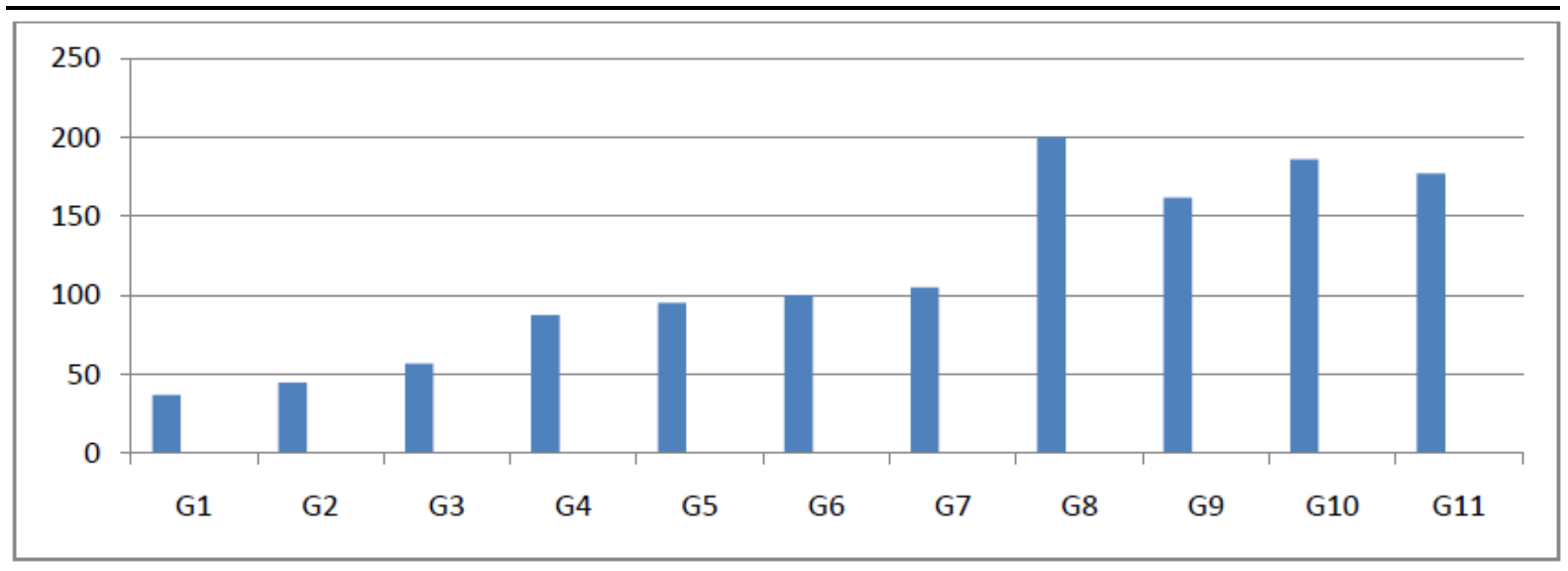

Fig6. Graphical representation of TSS

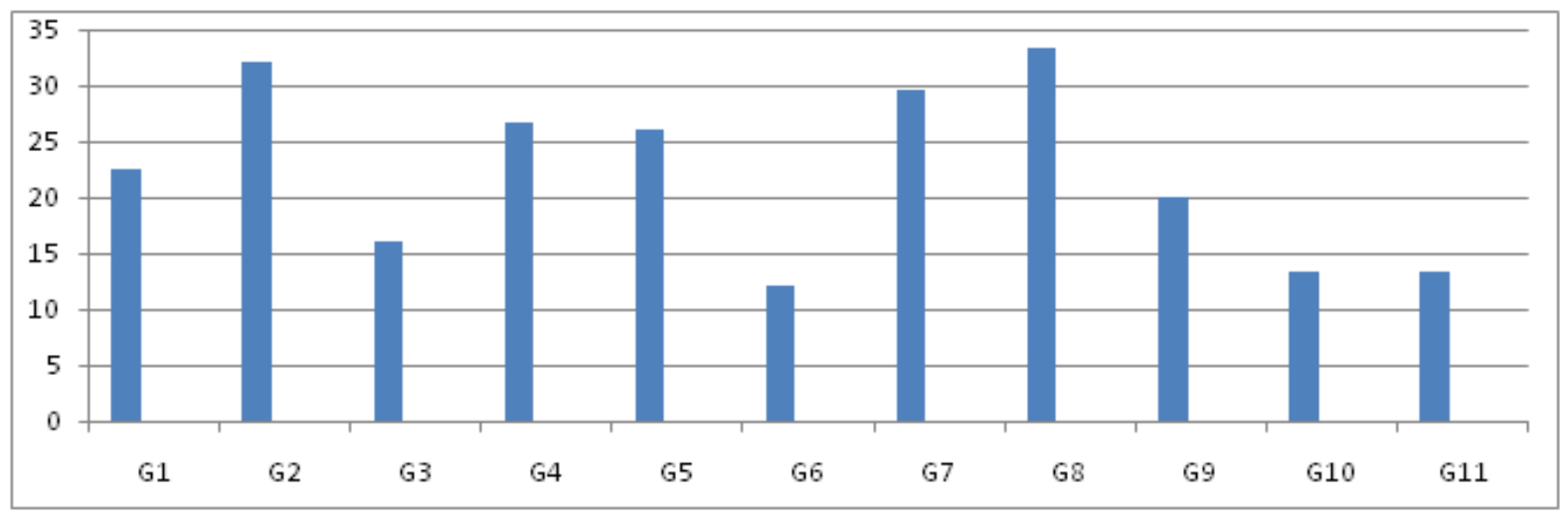

Fig7. Graphical representation of Alkalinity

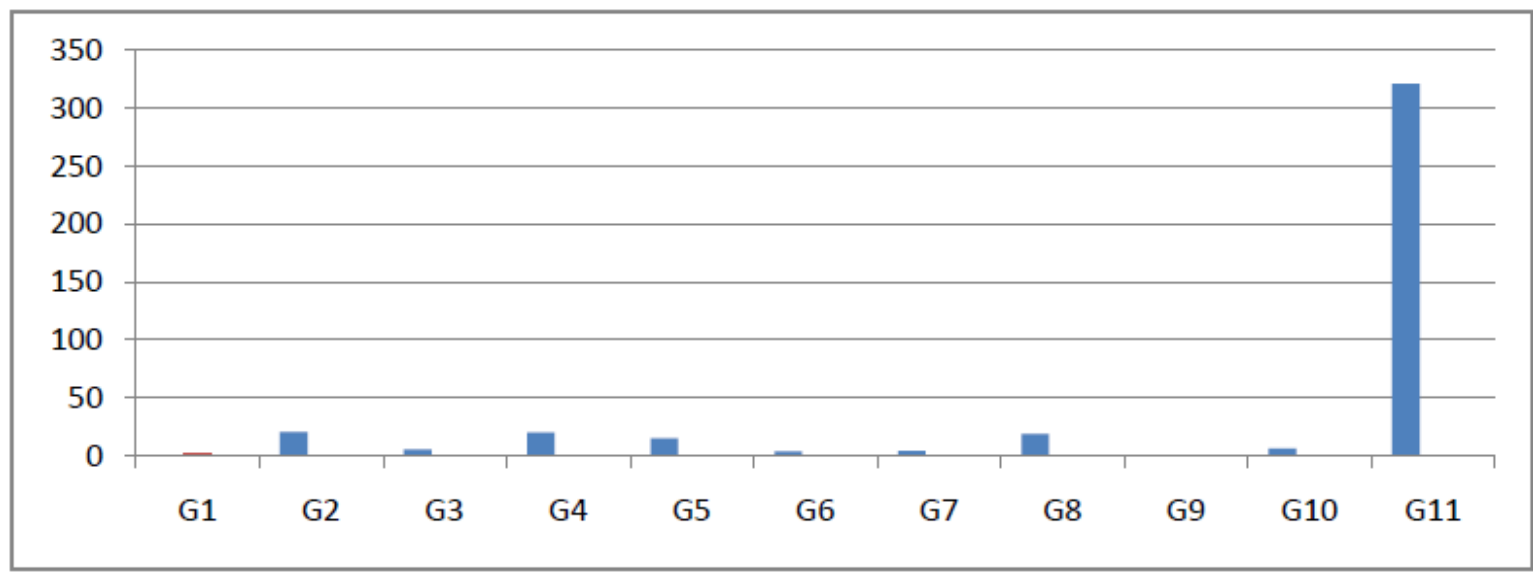

Fig8. Graphical representation of Nitrate

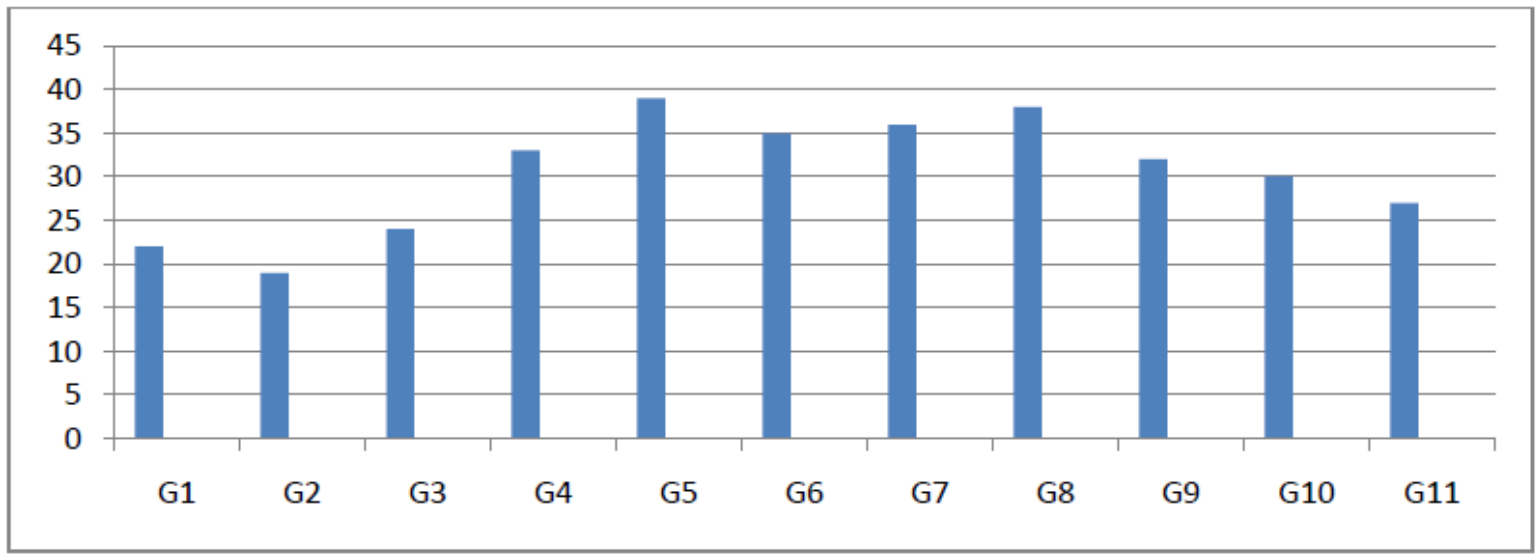

Fig9. Graphical representation of Chloride 


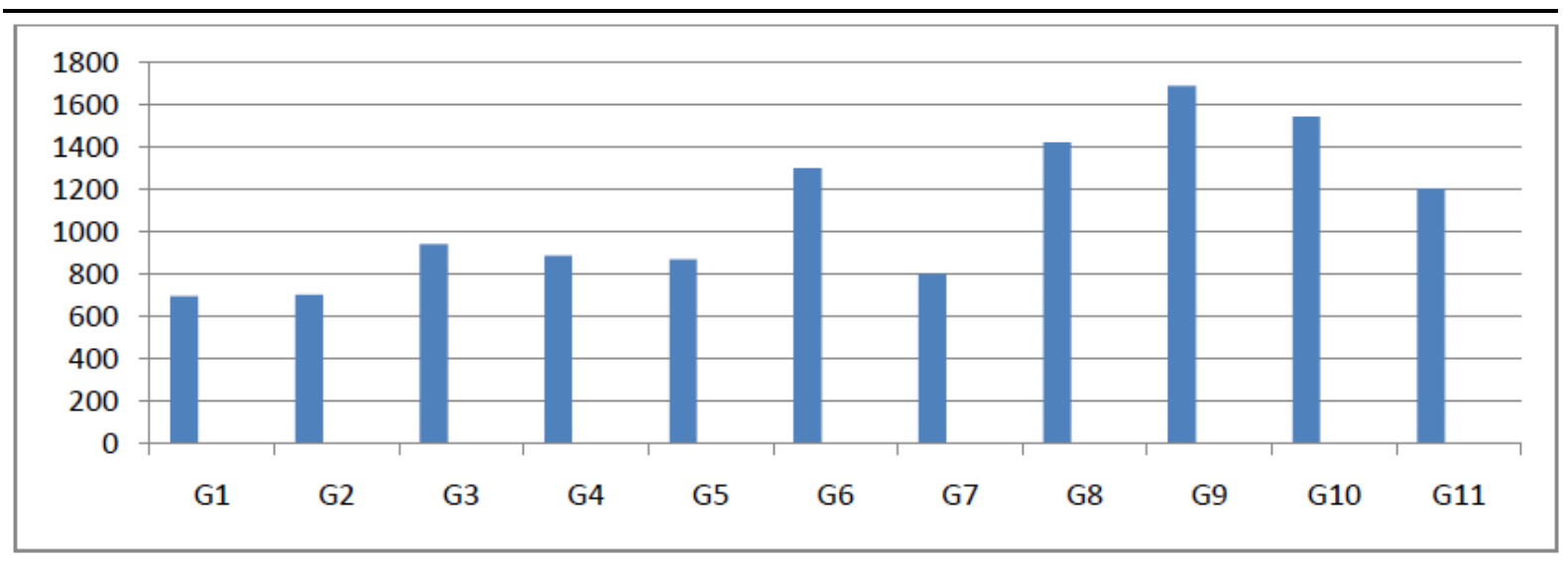

Fig10. Graphical representation of Total Hardness

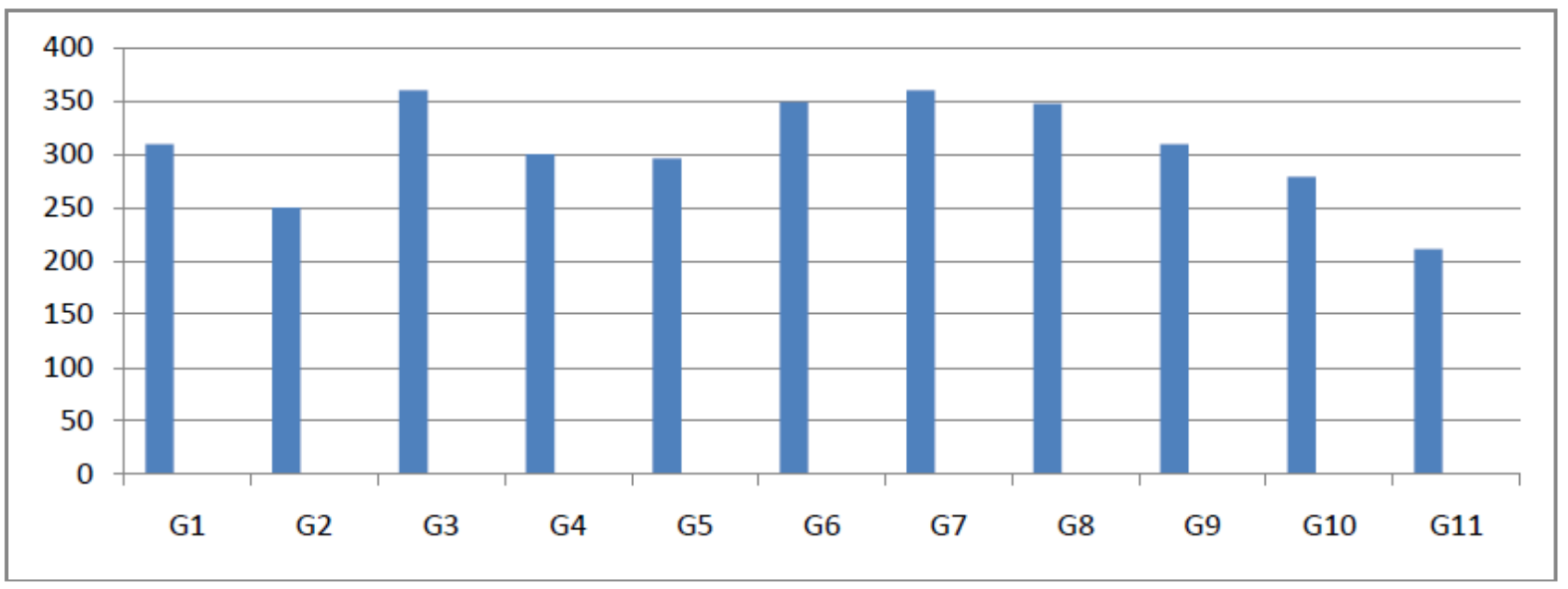

Fig11. Graphical representation of Sulphate

\section{Conclusion}

After analysis of physico-chemical Parameters of Ground Water samples from different location of chitrakoot region, it has been observed that some parameters are within the permissible limit while few were very higher than their maximum permissible limit. This is why; there of a better water quality management policy in corpora ting the following recommendations. Tube wells and other drinking water sources should be installed in a safety place. A proper's planning and management is required to mitigate the problem of drinking water contamination in Chitrakoot region of Satna District.

\section{REFERENCES}

[1] Tripathi Indra Prasd, Kumar M.Suresh and Dwivedi Arvind Prasad Characterization of Diffuse Chemical Pollution in Satna District of Vindhya Region, India of International Research Journal Chemical Environmental Sciences 2(11),46-60,(2013).

[2] Dwivedi SL, Pathak V, Hydro-chemical characteristics of Mandakini River at Chitrakoot, IJEP 27(11), 1006-1010, (2007).

[3] Hasan MZ, panday SP, Pathk BN, Bulusce. Project No.1428, Neeri Nagpur, (1981).

[4] ICMR, 1975. Manual of standards of quality for drinking water. ICMR Delli $2^{\text {nd }}$ ed (1975).

[5] Neeri, Manual on water and waste water analysis, Nagpur (1988).

[6] WHO, Guidelines for drinking water quality, Vol-2 Geneva (1984).

[7] APHA, AWWA and WPCF, Standard methods for the examination of water and waste water, $17^{\text {th }}$ Edition (1989).

[8] P. Mariya Pushpam, V. Umayoru Bhagan, G. Immanuel and A. Kumaraswamy, Assessment of Water Quality of Methusoothana Perumal Swamy Temple Pond in Parakkai, Kanyaumari, IJEP, 34 (9), 783- 788 (2014).

[9] K.B.L Shrivastav, S.P Mishra and Neerja Manlick, Ground Water Quality Assessment of Birsinghpur Area, Satna District, Madhya Pradesh, India, 1 (1), 125-132 (2014). 
[10] N. C. Das, Physico-chemical Characteristics of Selected Ground Water Samples of Ballarpur City of Chandrapur District, Maharashtra, India, International Research Journal of Environment Sciences, 2 (11), 96-100 (2013).

[11] Sadhana Chaurasia and Rajkaran, Pollution Sources and Water Quality of River Mandakini at Chitrakoot, IJEP ,33 (12), 969-977 (2013).

[12] Bita Mohanty Tanuja Panigrari, S.K. Tripathy and Dr. R. B. Panda, Assessment of Ground Water Quality Due to Coal Mining at Talabira-I Coal Mince, Sambalpur, Odisha, Journal of Applicable Chemistry, 3 (2), 764 - 768 (2014).

[13] Malik Suman, Panchorikanti and Amit Dubey, Water Quality Management of Water Resources of Bhopal City: Challenges and Scope, International research Journal of Environment Science, 3 (3), 22-26 (2014).

[14] V. Sunitha, V. Sudarshan, and B Rajeswara Reddy, Hydro geochemistry of Ground Water, Gooty Area, Anantpur District, Andhra Pradesh, India. Poll. Res, 24 (1), 217 - 224 (2005).

[15] Indra Prasad Tripathi, Arvind Prasad Dwivedi and M. Suresh Kumar, Assessment of Ground Water Quality in Umaria District, Vindhya Pradesh, India. Journal of Applicable Chemistry, 3 (2), 798- 811 (2014). 